\title{
Penerapan Teknik Make A Match untuk Meningkatkan Hasil Belajar Materi Perbandingan dan Skala pada Siswa Kelas VI SD
}

\author{
Lasmini
}

\author{
SDN 1 Sumberdadi Kecamatan Trenggalek Kabupaten Trenggalek \\ Email: lilik suherni@gmail.com
}

\begin{tabular}{l}
\hline Tersedia Online di \\
\hline http://www.jurnal.unublitar.ac.id/ \\
index.php/briliant \\
\hline \\
\hline Sejarah Artikel \\
\hline Diterima pada 5 Juni 2017 \\
Disetuji pada 23 Juni 2017 \\
Dipublikasikan pada: 2 Agustus \\
2017 Hal 260-271 \\
\hline Kata Kunci: \\
\hline make a match, prestasi \\
belajar, ips \\
\hline
\end{tabular}

\begin{abstract}
Abstrack: Masih banyak guru dalam mengajar matematika masih menggunakan metode belajar klasikal yakni ceramah yang bagi siswa sangat membosankan. Padahal metode pembelajaran yang variatif sangat membantu siswa untuk memahami materi pelajaran, diantaranya untuk meningkatkan hasil pembelajaran matematika. Salah satu metode pembelajaran yang dapat membantu untuk meningkatkan pembelajaran matematika di sekolah dasar adalaj metode make a match. Penelitian ini merupakan penelitian tindakian kelas (PTK). Hasil Penelitian menunjukkan peningkatan hasil dan ketuntasan belajar siswa, peningkatan hasil belajar siswa, di mana nilai hasil belajar siswa dari rata-rata pada studi awal hanya 50,91 , naik menjadi 60,91 pada siklus pertama, dan 75,45 pada siklus kedua.
\end{abstract}

Pelajaran matematika merupakan salah satu mata pelajaran yang di ajarkan di sekolah dasar. Hal ini menunjukan betapa pentingnya matematika, karena matematika sangat dibutuhkan dalam kehidupan sehari-hari. Fungsi matematika di sekolah dasar sebagai salah satu masukan instrumental dalam sistem proses belajar mengajar yang memiliki obyek dasar abstrak dan berazaskan kebenaran konsistensi. Dalam pembelajaran matematika para siswa dibiasakan untuk memperoleh pemahaman melalui pengalaman tentang sifat-sifat yang dimiliki dan tidak dimiliki dari sekumpulan obyek (abstraksi). Dengan pengamatan contoh-contoh dan bukan contoh-contoh khusus (generalisasi). Dalam proses penalarannya dikembangkan pola pikir induktif maupun deduktif.

Namun semua itu harus disesuaikan dengan perkembangan kemampuan siswa, sehingga pada akhirnya akan sangat membantu kelancaran proses pembelajaran matematika di sekolah dasar. Berdasarkan pengamatan pada sswa kelas VI SDN 1 Sumberdadi Kecamatan Trenggalek, menjelaskan masih banyak siswanya yang belum bisa memahami materi. Hal ini, ditunjukkan dengan rata-rata hasil belajar matematika siswa rendah. Banyak siswa yang mengalami kesulitan dalam menyelesaikan soal dengan benar. Kenyataan ini menunjukan bahwa pembelajaran matematika di kelas VI perlu ditingkatkan sesuai dengan tuntutan kurikulum yang ada di sekolah dasar.

Hal tersebut terbukti dari hasil pembelajaran Matematika pada siklus awal, hasil tes siswa kurang memuaskan Dari 11 siswa yang mendapatkan nilai di 
atas KKM hanya ada satu siswa atau 9,09\%, dan sebanyak 10 orang siswa atau $(90,91 \%)$ mendapatkan nilai di bawah KKM. Kenyataan ini masih jauh dari kriteria ketuntasan belajar yang telah ditetapkan yaitu secara klasikal $75 \%$ siswa mendapat nilai di atas KKM minimal 64.

Berdasarkan temuan-temuan pada pelaksanaan proses pembelajaran yang dilaksanakan sebelumnya, peneliti meminta bantuan teman sejawat dan kepala sekolah untuk membantu mengidentifikasi kekurangan dari pembelajaran yang sudah dilaksanakan. Dari hasil observasi dan diskusi terungkap beberapa masalah yang terjadi dalam pembelajaran, yaitu: (1) Banyaknya siswa yang menganggap mata pelajaran matematika itu susah dan tidak menyenangkan. (2) Minat belajar siswa pada materi sangat kurang. (3) Rendahnya hasil belajar siswa. (4) Kurangnya kemampuan siswa dalam memahami materi pelajaran yang disajikan oleh guru. (5) Ketidakberanian siswa dalam menanyakan materi pelajaran yang belum jelas atau belum dikuasai. (6) Ketidakseriusan siswa dalam pelaksanaan kegiatan pembelajaran yang ditunjukkan dengan banyaknya siswa yang kurang memperhatikan penjelasan yang diberikan guru selama proses pembelajaran berlangsung. (7) Pengaturan posisi duduk siswa kurang sesuai, sehingga persebaran siswa yang pandai dan tidak masih belum merata. (8) Keaktifan siswa dalam pelaksanaan proses pembelajaran kurang sesuai dengan harapan.

Kenyataan di lapangan tersebut menunjukkan masih banyak guru dalam mengajar matematika masih menggunakan metode belajar klasikal yakni ceramah yang bagi siswa sangat membosankan. Padahal metode pembelajaran yang variatif sangat membantu siswa untuk memahami materi pelajaran, diantaranya untuk meningkatkan hasil pembelajaran matematika. Salah satu metode pembelajaran yang dapat membantu untuk meningkatkan pembelajaran matematika di sekolah dasar adalaj metode make a match.

Make a match adalah teknik mengajar dengan mencari pasangan. Salah satu keunggulannya adalah siswa belajar sambil menguasai konsep atau topik dalam suasana yang menyenangkan. Pembelajaran teknik Make a match yaitu pembelajaran yang teknik mengajarnya dengan mencari pasangan melalui kartu pertanyaan dan jawaban yang harus ditemukan dan didiskusikan oleh pasangan siswa tersebut.

Teknik Make a Match atau mencari pasangan merupakan salah satu alternatif yang dapat diterapkan untuk meningkatkan hasil belajar siswa. Make a Match adalah pembelajaran menggunakan kartu-kartu. Kartu-kartu tersebut terdiri dari kartu yang berisi soal dan kartu yang lainnya berisi jawaban dari soal-soal tersebut. Make a Match adalah sistem pembelajaran yang mengutamakan penanaman kemampuan sosial terutama kemampuan bekerja sama, kemampuan berinteraksi disamping kemampuan berpikir cepat melalui permainan mencari pasangan dengan dibantu kartu (Wahab, 2007 : 59).

Teknik make a match atau mencari pasangan merupakan salah satu alternatif yang dapat diterapkan kepada siswa. Penerapan metode ini dimulai dari teknik yaitu siswa disuruh mencari pasangan kartu yang merupakan jawaban/soal sebelum batas waktunya, siswa yang dapat mencocokkan kartunya diberi poin. Teknik metode pembelajaran make a match atau mencari pasangan dikembangkan oleh Lorna Curran (1994). Salah satu keunggulan tehnik ini adalah siswa mencari pasangan sambil belajar mengenai suatu konsep atau topik dalam suasana yang menyenangkan 
Suyatno (2009: 72) mengungkapkan bahwa teknik make and match adalah model pembelajaran dimana guru menyiapkan kartu yang berisi soal atau permasalahan dan menyiapkan kartu jawaban kemudian siswa mencari pasangan kartunya. Model pembelajaran make and match merupakan bagian dari pembelajaran kooperatif. Model pembelajaran kooperatif didasarkan atas falsafah homo homini socius, falsafah ini menekankan bahwa manusia adalah mahluk sosial (Lie, 2003:27). Model make and match melatih siswa untuk memiliki sikap sosial yang baik dan melatih kemampuan siswa dalam bekerja sama disamping melatih kecepatan berfikir siswa.

Langkah-langkah penerapan metode make a match sebagai berikut: (1) Guru menyiapkan beberapa kartu yang berisi beberapa konsep atau topik yang cocok untuk sesi review, satu bagian kartu soal dan bagian lainnya kartu jawaban. (2) Setiap siswa mendapatkan sebuah kartu yang bertuliskan soal/ jawaban. (3) Tiap siswa memikirkan jawaban/ soal dari kartu yang dipegang. (4) Setiap siswa mencari pasangan kartu yang cocok dengan kartunya. Misalnya: pemegang kartu yang bertuliskan bela negara akan berpasangan dengan kartu yang bertuliskan soal "sikap dan perilaku warga negara yang dijiwai oleh kecintaannya kepada negara dalam menjamin kelangsungan hidup bangsa dan negara". (5) Setiap siswa yang dapat mencocokkan kartunya sebelum batas waktu diberi poin. (6) Jika siswa tidak dapat mencocokkan kartunya dengan kartu temannya (tidak dapat menemukan kartu soal atau kartu jawaban) akan mendapatkan hukuman, yang telah disepakati bersama. (7) Setelah satu babak, kartu dikocok lagi agar tiap siswa mendapat kartu yang berbeda dari sebelumnya, demikian seterusnya. (8) Siswa juga bisa bergabung dengan 2 atau 3 siswa lainnya yang memegang kartu yang cocok. (9) Guru bersama-sama dengan siswa membuat kesimpulan terhadap materi pelajaran.

Berdasarkan kondisi sebagaimana disampaikan di atas, maka akan dilakukan Penelitian Untuk mengetahui peningkatan hasil belajar mata pelajaran materi perbandingan dan skala melalui teknik make a match bagi siswa kelas VI Sekolah dasar.

\section{METODE}

Penelitian ini merupakan penelitian tindakian kelas (PTK). Penelitian tindakan kelas (PTK) adalah penelitian yang dilakukan oleh guru untuk mencari berbagai macam kekurangan yang terdapat dalam pembelajaran untuk kemudian dilakukan perbaikan. Menurut Wardani, dkk (2006 : 2.4), Perbaikan pembelajaran dilaksanakan melalui proses pengkajian berdaur, yang terdiri dari empat tahap yaitu perencanaan (plan), pelaksanaan (action), mengamati (observation), dan refleksi (reflection). Secara rinci dapat dilihat pada gambar di bawah ini : 


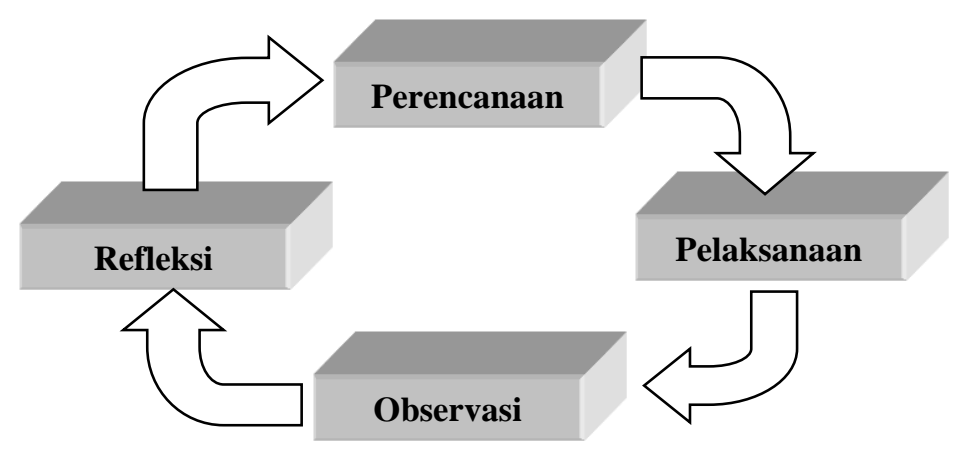

\section{Gambar 1 Tahap-tahap dalam Penelitian Tindakan Kelas (Wardani IGAK, 2006:4)}

\section{Perencanaan}

Perencanaan selalu mengacu kepada tindakan apa yang dilakukan, dengan mempertimbangkan keadaan dan suasana obyektif dan subyektif. Dalam perencanaan tersebut, perlu dipertimbangkan tindakan khusus apa yang dilakukan, apa tujuannya. Mengenai apa, siapa melakukan, bagaimana melakukan, dan apa hasil yang diharapkan. Setelah pertimbangan itu dilakukan, maka selanjutnya disusun gagasan-gagasan dalam bentuk rencana yang dirinci. Kemudian gagasangagasan itu diperhalus, hal-hal yang tidak penting dihilangkan, pusatkan perhatian pada hal yang paling penting dan bermanfaat bagi upaya perbaikan yang dipikirkan. Sebainya perencanaan tersebut didiskusikan dengan Guru yang lain untuk memperoleh masukan.

\section{Pelaksanaan Tindakan}

Jika perencanan yang telah dirumuskan sebelumnya merupakan perencanaan yang cukup matang, maka proses tindakan semata-mata merupakan pelaksanaan perencanaan itu. Namun, kenyataan dalam praktik tidak sesederhana yang dipikirkan. Oleh sebab itu, pelaksanaan tindakan boleh jadi berubah atau dimodifikasi sesuai dengan keperluan di lapangan. Tetapi jangan sampai modifikasi yang dilakukan terlalu jauh menyimpang. Jika perencanaan yang telah dirumuskan tidak dilaksanakan, maka Guru hendaknya merumuskan perencanaan kembali sesuai dengan fakta baru yang diperoleh.

\section{Pengamatan}

Hal yang tidak bisa dilupakan, bahwa sambil melakukan tindakan hendaknya juga dilakukan pemantauan secara cermat tentang apa yang terjadi. Dalam pemantauan itu, lakukan pencatatan-pencatatan sesuai dengan form yang telah disiapkan. Catat pula gagasan-gagasan dan kesan-kesan yang muncul, dan segala sesuatu yang benar-benar terjadi dalam proses pembelajaran. Secara teknis operasional, kegiatan pemantauan dapat dilakukan oleh Guru lain. Di sinilah letak kerja kolaborasi antar profesi. Namun, jika petugas pemantau itu bukan rekanan peneliti, sebaiknya diadakan sosialisasi materi pemantauan untuk menjaga agar data yang dikumpulkan tidak terpengaruh minat pribadinya. Untuk memperoleh data yang lebih obyektif, Guru dapat menggunakan alat alat optik atau elektronik, seperti kamera, perekam video, atau perekam suara. Pada setiap kali akan mengakhiri penggalan kegiatan, lakukanlah evaluasi terhadap hal-hal yang telah 
direncanakan. Jika observasi berfungsi untuk mengenali kualitas proses tindakan, maka evaluasi berperanan untuk mendeskripsikan hasil tindakan yang secara optimis telah dirumuskan melalui tujuan tindakan.

\section{Refleksi}

Refleksi adalah suatu upaya untuk mengkaji apa yang telah terjadi, yang telah dihasilkan, atau apa yang belum dihasilkan, atau apa yang belum tuntas dari langkah atau upaya yang telah dilakukan. Dengan perkataan lain, refleksi merupakan pengkajian terhadap keberhasilan atau kegagalan pencapaian tujuan. Untuk maksud ini, Guru hendaknya terlebih dahulu menentukan kriteria keberhasilan.

\section{Subjek Penelitian}

Subjek penelitian adalah siswa kelas VI SD Negeri 1 Sumberdadi dengan jumlah siswa sebanyak 11 siswa terdiri dari 6 siswa laki-laki dan 5 siswa perempuan

\section{Instrumen Penelitian}

Lembar observasi, lembaran ini yaitu lembar observasi untuk siswa. Penelitian menggunakan lembar observasi untuk memberikan gambaran mengenai sikap siswa dalam belajar, sikap guru dalam memberikan pelajaran, serta interaksi siswa dengan guru juga siswa dengan siswa selama proses pembelajaran berlangsung. Selain itu lembar observasi ini bertujuan untuk mengetahui kekurangan-kekurangan yang harus diperbaiki atau kelebihankelebihan yang harus dipertahankan dan ditingkatkan pada pembelajaran berikutnya

\section{Teknik Pengumpulan Data}

Penilaian atau tes, merupakan teknik penilaian bertujuan untuk mengetahui sejauh mana perkembangan dan kemajuan proses dari hasil belajar siswa serta mengumpulkan data dan informasi dalam rangka usaha perbaikan kegiatan pembelajaran. Data hasil penilaian dapat pula digunakan untuk mengetahui keefektifan pendekatan yang digunakan.

\section{Teknik Analisis Data}

Analisis data dilaksanakan secara kualitatif dan kuantitatif pada setiap akhir siklus pembelajaran serta data hasil belajar siswa, data yang dianalisis meliputi data hasil observasi kegiatan guru dan aktifitas siswa

\section{Data hasil observasi minat belajar siswa}

Indikator minat belajar yang diamati terdiri dari 8 indikator yaitu adalah perasaan senang, perhatian terhadap bahan pelajaran, memahami materi pelajaran dan menyelesaikan soal-soal pelajaran, ketertarikan terhadap bahan pelajaran, ketertarikan untuk menyelesaikan soal-soal pelajaran, rasa senang mengetahui bahan belajar, memahami bahan belajar, dan kemampuan menyelesaikan soalsoal. Kriteria yang digunakan adalah Sangat Baik (SB), Baik (B), Cukup (C), dan Kurang (K). 
Tabel 1 Kriteria Penilaian Hasil Observasi Minat Belajar Siswa

\begin{tabular}{|cll|}
\hline Rentang & Kategori & Ketuntasan \\
\hline $\mathbf{8 9 - 1 0 0}$ & Sangat Baik & Tuntas \\
\hline $\mathbf{7 9 - 8 8}$ & Baik & Tuntas \\
\hline $\mathbf{6 9 - 7 8}$ & Cukup & Belum Tuntas \\
\hline$<69$ & Kurang & Belum Tuntas \\
\hline
\end{tabular}

\section{Data hasil belajar}

Hasil belajar siswa dianalisis secara kuantitif. Menurut Arikunto (2011:45) analisis data dimaksudkan untuk mengetahui ketuntasan belajar siswa dalam kegiatan belajar mengajar. Perolehan nilai setiap siswa melalui tes hasil belajar menggunakan kriteria sebagai berikut :

Tabel 2 Kriteria Penilaian Hasil Belajar

\begin{tabular}{|c|l|l|}
\hline Nilai & Ketuntasan & Keterangan \\
\hline$>=65$ & Tuntas & \\
\hline$<65$ & Belum Tuntas & \\
\hline
\end{tabular}

Perolehan nilai setiap siswa melalui tes hasil belajar secara tertulis diolah dengan rumus:

\section{Ketuntasan Belajar Klasikal}

Keterangan :

$$
a=\frac{b}{c} \times 100 \%
$$

A $=$ Ketuntasan

$\mathrm{B}=$ Jumlah Siswa Tuntas (siswa mendapat nilai di atas 65)

C = Jumlah Seluruh Siswa

\section{Nilai rata-rata}

$$
X=\frac{\sum Y}{n}
$$

Keteranga:

$\mathrm{X}=$ Nilai Rata-rata

$\sum \mathrm{Y}=$ Jumlah Nilai Seluruh Siswa

$\mathrm{n}=$ Jumlah Seluruh Siswa

Mencari nilai rata-rata kelas. Rumus: Rata-Rata $=$ Jumlah skor seluruhnya/Jumlah siswa (24). Mencari prosentase ketuntasan. Rumus : 
Ketuntasan $=($ Jumlah Siswa Tuntas /jumlah siswa) $\mathrm{x} 100 \%$. Menentukan modus/nilai yang sering muncul Menentukan peningkatan prestasi belajar, dengan rumus : Prosentase peningkatan prestasi belajar $=$ selisih nilai siklus I dan siklus II x $100 \%$.

\section{HASIL}

\section{Siklus I}

Berdasarkan hasil tes dan observasi selama proses pembelajaran oleh observer didapat kesimpulan bahwa proses pembelajaran belum berjalan dengan baik. Pada siklus pertama proses belajar siswa sedikit mengalami perubahan ke arah yang lebih baik daripada sebelumnya (studi awal).

Dari dua kali pertemuan pada pelaksanaan perbaikan pembelajaran pada siklus pertama dianggap belum berhasil. Oleh karena itu, peneliti dan observer mendiskusikan tentang hasil observasi dan mewawancarai yang telah dilakukan dan dikaitkan dengan hasil tes, maka proses perbaikan pembelajaran pada siklus kedua perlu dilakukan dengan memperbanyak latihan-latihan soal dengan pengintensifan metode pembelajaran make a match dilanjutkan diskusi kelas untuk pembahasan hasil tes.

Data hasil pelaksanaan tindakan pada pembelajaran matematika penerapan metode pembelajaran make a match sebagaimana dijelaskan tabel di bawah ini :

Tabel 3 Rekapitulasi Nilai Tes Pembelajaran Matematika pada Siklus I

\begin{tabular}{|c|c|c|c|c|c|c|}
\hline \multirow{2}{*}{ Nilai } & \multirow{2}{*}{$\begin{array}{c}\text { Sumlah } \\
\text { Siswa }\end{array}$} & \multirow{2}{*}{ Capaian } & \multicolumn{5}{|c|}{ Tuntas } \\
\hline & & Ya & $\%$ & Tidak & $\%$ \\
\hline 40 & 0 & 0 & & & & \\
\hline 50 & 4 & 200 & & & $\sqrt{ }$ & 36.36 \\
\hline 60 & 3 & 180 & & & $\sqrt{ }$ & 27.27 \\
\hline 70 & 3 & 210 & $\sqrt{ }$ & 27.27 & & \\
\hline 80 & 1 & 80 & $\sqrt{ }$ & 9.09 & & \\
\hline D 90 & 0 & 0 & & & & \\
\hline 100 & 0 & 0 & & & & \\
\hline Jumlah & 11 & 670 & - & $\mathbf{3 6 . 3 6}$ & - & $\mathbf{6 3 . 6 4}$ \\
\hline Nilai >= KKM & \multicolumn{7}{|c|}{$\mathbf{3 6 . 3 6}$} \\
\hline Nilai Rata-2 & \multicolumn{7}{|c|}{$\mathbf{6 0 . 9 1}$} \\
\hline
\end{tabular}

Dari tabel di atas tentang rekapitulasi nilai tes pembelajaran matematika di atas dapat diterangkan dapat diterangkan bahwa pada kondisi awal nilai ratarata hasil belajar 50,91 setelah dilakukan perbaikan mengalami kenaikan menjadi 60,91. dan jumlah siswa yang telah mencapai tingkat ketuntasan belajar 4 siswa $(36,36 \%)$. Dari penjelasan di atas, peneliti bersama observer sepakat bahwa pelaksanaan pembelajaran perlu dilanjutkan pada siklus II, karena prestasi belajar siswa belum mencapai perolehan di atas KKM sebesar 65,00 dengan tingkat ketuntasan belajar mencapai angka di atas $85 \%$.

\section{Siklus II}

Pada siklus kedua proses belajar siswa sedikit mengalami perubahan ke arah yang lebih baik daripada sebelumnya (siklus I). Demikian pun dengan hasil 
belajar siswa mengalami perbaikan ke arah peningkatan yang diharapkan. Hasil observasi dan pengamatan ternyata masuk dalam kategori cukup baik karena siklus kedua, dari 11 siswa, sebanyak 10 siswa $(90,91 \%)$ dinyatakan tuntas belajar, sementara satu orang $(9,09 \%)$ Adapun penjelasan mengenai peningkatan minat belajar siswa adalah 11 siswa (100\%) dinyatakan mengalami peningkatan minat belajarnya dalam mengikuti proses pembelajaran dari 11 siswa seluruhnya, sedangkan nilai rata-rata hasil belajar mencapai 75,45. Melihat kenyataan di atas dapat dinyatakan bahwa pembelajaran belum tuntas dan yang akan menjadi fokus perhatian pada pelaksanaan siklus kedua. Dari hasil diskusi dengan supervisor dan observer kelemahan pada siklus kedua ini akan ditanggulangi dengan lebih mengintensifkan penggunaan metode pembelajaran make a match secara leih intensif

Data hasil pelaksanaan tindakan pada pembelajaran matematika menggunakan metode pembelajaran make a match sebagaimana dijelaskan tabel di bawah ini :

\section{Tabel 4 Rekapitulasi Nilai Tes Pembelajaran Matematika pada Siklus II}

\begin{tabular}{|c|c|c|c|c|c|c|}
\hline \multirow{2}{*}{ Nilai } & Jumlah & \multirow{2}{*}{ Capaian } & \multicolumn{5}{|c|}{ Tuntas } \\
\cline { 4 - 7 } & Siswa & & Ya & $\%$ & Tidak & $\%$ \\
\hline 40 & 0 & 0 & & & & \\
\hline 50 & 0 & 0 & & & & \\
\hline 60 & 1 & 60 & & & $\sqrt{ }$ & 9.09 \\
\hline 70 & 4 & 280 & $\sqrt{ }$ & 36.36 & & \\
\hline 80 & 5 & 400 & $\sqrt{ }$ & 45.45 & & \\
\hline 90 & 1 & 90 & $\sqrt{ }$ & 9.09 & & \\
\hline 100 & 0 & 0 & & & & \\
\hline Jumlah & 11 & $\mathbf{8 3 0}$ & - & $\mathbf{9 0 . 9 1}$ & - & $\mathbf{9 . 0 9}$ \\
\hline Nilai >= KKM & \multicolumn{7}{|c|}{$\mathbf{9 0 . 9 1}$} \\
\hline Nilai Rata-2 & \multicolumn{7}{|c|}{$\mathbf{7 5 . 4 5}$} \\
\hline
\end{tabular}

Dari tabel di atas tentang rekapitulasi nilai prestasi belajar pembelajaran matematika dengan menggunakan metode pembelajaran make a match di atas dapat diterangkan sebagai berikut pada siklus I nilai rata-rata hasil belajar 60,91 setelah dilakukan perbaikan mengalami kenaikan menjadi 75,45. Rata-rata hasil belajar naik 14,55, dan jumlah siswa yang telah mencapai tingkat ketuntasan belajar $10(90,911 \%)$

Melihat hasil di atas maka peneliti bersama-sama dengan observer menyimpulkan bahwa hasil tes prestasi belajar menunjukkan hasil 75,45. Hal ini menunjukkan bahwa tes prestasi belajar sudah memenuhi kriteria keberhasilan karena berada di atas angka kriteria minimal ketuntasan (KKM) sebesar 65, dengan jumlah siswa yang telah tuntas belajarnya sebanyak 10 siswa atau 90,91\% dan telah mencapai kriteria keberhasilan sebesar $85 \%$.

\section{PEMBAHASAN}

\section{Siklus I}

Pada siklus I, proses belajar siswa sedikit mengalami perubahan ke arah yang lebih baik daripada sebelumnya (studi awal). Demikian pun dengan hasil 
belajar siswa mengalami perbaikan ke arah peningkatan yang diharapkan. Peningkatan hasil dan ketuntasan belajar meningkat cukup baik, yaitu dari nilai rata-rata hasil belajar mencapai 62,31 dari nilai rata-rata hasil belajar sebesar 53,46 pada kondisi awal dengan ketuntasan belajar meningkat menjadi 11 siswa atau $42,31 \%$.

Melihat hasil di atas maka peneliti bersama-sama dengan observer sepakat untuk melaksanakan perbaikan pembelajaran pada siklus II dengan harapan pada siklus II rata-rata hasil belajar siswa dapat mencapai perolehan di atas KKM sebesar 65, dan 85\% untuk ketuntasan belajar siswa.

Dari hasil diskusi antara peneliti dengan observer tentang hasil observasi dan wawancara dikaitkan dengan hasil tes, penyebab ketidakberhasilan pelaksanaan pembelajaran pada siklus pertama disebabkan oleh beberapa faktor diantaranya: (1) Penjelasan yang diberikan masih bersifat abstrak sehingga siswa masih kesulitan memahami penjelasan yang diberikan guru tentang materi pembelajaran menggunakan metode pembelajaran make a match. (2) Sebagian besar siswa masih kurang memahami sepenuhnya terhadap materi pembelajaran yang diberikan, terutama pada saat penyajian materi menggunakan metode pembelajaran make a match

Dari kenyataan temuan pada saat pelaksanaan siklus pertama, maka peneliti bersama-sama dengan observer memutuskan untuk mengadakan perbaikan pada siklus kedua dengan menerapkan: (1) Guru lebih memberikan bimbingan kepada siswa selama proses pembelajaran menggunakan metode make a match. (2) Guru harus mempergunakan waktu selama proses pembelajaran dengan sebaik-baiknya. (3) Membatasi kegiatan pembelajaran dengan make a match sebaik mungkin dan tidak membiarkan kegiatan siswa lebih banyak pada bermain dan berbincang dengan teman.

\section{Siklus II}

Pada siklus kedua proses belajar siswa sedikit mengalami perubahan ke arah yang lebih baik daripada sebelumnya (siklus kedua). Demikian pun dengan hasil belajar siswa mengalami perbaikan ke arah peningkatan yang diharapkan.

Peningkatan hasil dan ketuntasan belajar meningkat yaitu dari nilai ratarata hasil belajar sebesar 60,91 pada siklus pertama, menjadi 75,45 pada siklus kedua, sedangkan tingkat ketuntasan belajar mencapai angka 90,91\% atau 10 siswa. Melihat hasil di atas maka peneliti bersama-sama dengan observer menyimpulkan bahwa hasil tes hasil belajar menunjukkan hasil 75,45 . Hal ini menunjukkan bahwa tes hasil belajar sudah memenuhi kriteria keberhasilan karena hasil belajar berada di atas angka kriteria minimal ketuntasan (KKM) sebesar 65 dan ketuntasan belajar sebesar 90,91\% atau sudah berada di atas kriteria minimal sebesar $85 \%$, sehingga proses perbaikan pembelajaran dinyatakan berhasil dan tuntas pada pelaksanaan siklus II

Keberhasilan pelaksanan perbaikan pembelajaran pada siklus kedua dibuktikan oleh beberapa faktor diantaranya pembelajaran berlangsung sangat kondusif dan interaktif. Siswa tampak senang belajar, jumlah siswa yang tuntas sudah jauh melampuai kriteria yang ditetapkan, serta didukung oleh peningkatan minat belajar siswa yang meningkat sangat signifikan. Pada siklus II ini, angka peningkatan ketuntasan belajar naik menjadi 90,91\% (bertambah 6 siswa dari siklus I), pada siklus I, nilai rata-rata hasil belajar mengalami kenaikan sebesar 
10,00 dari studi awal menjadi 60,91, dan pada siklus II, nilai rata-rata hasil belajar mengalami kenaikan sebesar 14,55 dari siklus I menjadi 75,45.

\section{Pembahasan Secara Umum}

Dari pelaksanaan proses perbaikan pembelajaran melalui penelitian tindakan kelas yang dilaksanakan dalam dua siklus, dapat ditarik kesimpulan bahwa pelaksanaan proses perbaikan pembelajaran berjalan baik dan mengalami peningkatan yang signifikan pada setiap siklusnya. Peningkatan minat siswa menunjukkan perolehan pada studi awal hanya 3 siswa atau $27,27 \%$, naik menjadi 8 siswa atau $72,72 \%$ pada siklus pertama, $100 \%$ atau dapat dinyatakan bahwa semua siswa pada siklus kedua dinyatakan mengalami peningkatan minat belajar selama mengikuti kegiatan pembelajaran. Kenyataan di atas didukung pula oleh peningkatan prestasi belajar prestasi hasil belajar siswa dari rata-rata pada studi awal hanya 50,91, naik menjadi 60,91 pada siklus pertama, dan 75,45 pada siklus kedua, dengan tingkat ketuntasan belajar sebanyak 1 siswa $(9,09 \%)$ pada studi awal, 36,36\% atau 4 siswa pada siklus pertama, dan pada siklus terakhir menjadi $90,91 \%$, atau 10 siswa, dan masih ada satu orang siswa $(9,09 \%)$ yang belum tuntas, sehingga semua kriteria ketuntasan telah tercapai pada siklus kedua. Hal tersebut sesuai dengan pernyataan Nasution, S (1982: 36) menyebutkan bahwa mastery learning atau belajar tuntas, artinya penguasaan penuh. Penguasaan penuh ini dapat dicapai apabila siswa mampu menguasai materi tertentu secara menyeluruh yang dibuktikan dengan prestasi belajar yang baik pada materi tersebut.

\section{SIMPULAN}

Penggunaan metode pembelajaran make a match terbukti dapat meningkatkan hasil dan ketuntasan belajar siswa, peningkatan hasil belajar siswa, di mana nilai hasil belajar siswa dari rata-rata pada studi awal hanya 50,91 , naik menjadi 60,91 pada siklus pertama, dan 75,45 pada siklus kedua, dengan tingkat ketuntasan belajar sebanyak 1 siswa $(9,09 \%)$ pada studi awal, 36,36\% atau 4 siswa pada siklus pertama, dan pada siklus terakhir menjadi 90,91\%, atau 11 siswa, dan masih ada satu orang siswa $(9,09 \%)$ yang belum tuntas, sehingga semua kriteria ketuntasan telah tercapai pada siklus kedua

Mengingat pembelajaran dilakukan di kelas VI, dengan mata pelajaran Matematika, dimana sering terhambat pada kesiapan siswa dan motivasi yang tidak tetap terhadap pelajaran tersebut, maka seyogyanya model pembelajaran yang mengandung nilai pakem sangat perlu diperlukan. Khususnya suasana pembelajaran yang menyenangkan, sehingga dalam pelaksanaan pembelajaran siswa mampu mendalami materi secara lebih baik. Guru hendaknya bersifat kooperatif dan mau membawa konsepsi awal siswa dalam kegiatan pembelajaran. Serta dapat menerapkan pembelajaran make a match pada materi pembelajaran yang sejenis / sama untuk pelaksanaan pembelajaran berikutnya, karena dengan metode pembelajaran make a match akan melibatkan pengalaman langsung, berfikir dan merasakan atas kehendak sendiri dan melibatkan seluruh peserta didik. 


\section{DAFTAR RUJUKAN}

Abdurrahman, Mulyono. 2006. Pendidikan Anak Berkesulitan Belajar. Jakarta: Rineka. Cipta

Arikunto, Suharsimi. 1996. Prosedur Penelitian: Suatu Pendekatan Praktek. Jakarta: Rhineka Cipta.

Crow, A., \& Crow, L. 1984. Psychologi Pendidikan. Yogyakarta: Nur Cahaya.

Depdiknas. (2003). Undang-Undang Republik Indonesia No. 20 Tahun 2003 tentang Sistem Pendidikan Nasional. Depdiknas. Jakarta.

Dimyati dan Madjiono, (1999), Belajar dan Pembelajaran, Jakarta: Rineka Cipta

Dimyati dan Mudjiono. 2002. Belajar dan Pembelajaran. Depdikbud. Jakarta.

Ginting, Vera. 2005. Penguatan Membaca, Fasilitas Lingkungan Sekolah dan Keterampilan Dasar Membaca Bahasa Indonesia serta Minat Baca Murid. Jakarta :Jurnal Pendidikan Penabur. No.04/ Th.IV/ Juli 2005

Hamzah B. Uno. 2007. Model Pembelajaran. Bumi Aksara. Jakarta.

Heruman. 2007. Model Pembelajaran Matematika di Sekolah Dasar. Bandung : Remaja Rosdakarya.

Hudoyo, Herman. 1997. Pengembangan Kurikulum Matematika di depan Kelas. Usaha Nasional. Surabaya.

Hurlock, E.B. 1993. Adolecent Development, McGraw-Hill, Kogakusha, Ltd. Tokyo.

Marlina 2004. Optimalisasi Penggunaan Alat peraga Untuk Mengatasi Kesulitan Siswa Dalam Menyelesaikan Soal Cerita Matematika Di Kelas II SDN Tanjung 2 Bojong Loa Kaler Kota Bandung; Skripsi, UPI. Bandung.

Mulyono, Anton. 1990. Kamus Besar Bahas Indonesia. Balai Pustaka. Jakarta.

Nashar, Drs. 2004. Peranan Motivasi dan Kemampuan Awal dalam Kegiatan Pembelajaran. Delia Press. Jakarta.

Posavac, Emil J and Raymond G. Carey, 1980, Program Evaluation : Methods and Case Studies, New Jersey : Pretince-Hall

Priatna, D. Ujang. (2005). Belajar Aktif dan Terpadu: Apa, Mengapa dan Bagaimana. Surabaya: Duta Graha Pustaka.

Ruseffendi, E.T. (1992). Dasar-dasar penelitian Pendidikan dan Bidang NonEksakta Lainnya. Cetakan Kedua. IKIP Semarang Press. Semarang.

Ruseffendi. (1991). Pengantar Kepada Membantu Guru Mengembangkan Kompetensinya Dalam Pengajaran Matematika Untuk Meningkatkan CBSA. Bandung: Tarsito.

Sardiman A.M, 1989, Interaksi dan Motivasi Belajar Mengajar, Rajawali Press. Jakarta.

Slameto. 2003. Belajar dan Faktor-Faktor yang Mempengaruhinya. Jakarta: Rineka Cipta

Sudjana Nana. 2004. Landasan Psikologi Pendidikan. Jakarta: Remaja Rosdakarya.

Sumantri, Mulyani dan Johar Permana. (1998). Strategi Belajar Mengajar. CV. Gramedia Press. Jakarta.

Suyanto. (1997) Pedoman Pelaksanaan Penelitian Kelas. Dirjen Dikti. Jakarta.

Usman, Uzer. 1995. Menjadi Guru Profesional. PT. Remaja Rosdakarya. Bandung. 
Wardani Sri, Teknik Pengembangan Silabus dan Program Penilaian Pembelajaran Matematika, Yogyakarta: PPPG matematika, 2004.

Wardani, I.G.A.K, Julaeha. S, dan Marsinah Ng. 2002. Pemantapan Kemampuan Profesional (Panduan). Universitas Terbuka. Jakarta.

Widiyarni, Dyah R. 2008. Keberhasilan Mengajar Belajar. Remaja Karya. Jakarta.

Wina Sanjaya. (2005). Pembelajaran dalam Implementasi Kurikulum Berbasis Kompetensi. Jakarta: Kencana Prenada Media Grup. 